\title{
THE INFLUENCE OF INSTRUCTIONAL METHOD ON STUDENTS' ACHIEVEMENT AND MENTAL EFFORT: SYSTEMIC VERSUS TRADITIONAL APPROACH IN SECONDARY ORGANIC CHEMISTRY TEACHING ${ }^{1}$
}

\begin{abstract}
Organic chemistry is the chemical discipline that many secondary school students find abstract and difficult. As a result, they learn organic chemistry concepts in a "rote" way. Therefore, the first goal of this study was to examine whether the systemic approach, that implies the application of systemic synthesis questions, [SSynQs], as new instructional tools, could help students in overcoming these difficulties. The results of this study have shown that students from the experimental group, who were exposed to the new instructional method, achieved higher scores on final testing than students from the control group, who were taught by traditional method, when students' achievements in conventional linear questions, [LQs], and systemic synthesis question, [SSynQs], were evaluated. These findings were followed by the reduction of levels of invested mental effort of the students from experimental group, estimated during solving both types of test questions. Additionally, it was confirmed that students from both examined groups find systemic synthesis question, [SSynQs], more difficult to solve than linear questions, [LQs], achieving lower scores and perceiving higher levels of mental effort. These research findings were explained by completion problems effect which is often discussed within cognitive load theory. Having this in mind, the next step in our research would be to examine the influence of variability effect on students' ability to solve systemic synthesis question, [SSynQs].
\end{abstract}

Keywords: Systemic approach to teaching and learning chemistry, systemic synthesis questions [SSynQs], conventional linear questions [LQs], achievement, mental effort.

$1 \quad$ This work has been supported by Grant No. 179010 (project The Quality of Education System in Serbia from European Perspective), from the Ministry of Education, Science and Technological Development of the Republic of Serbia. 
Tamara Hrin, Mirjana Segedinac, Dušica Milenković, Saša Horvat

\title{
УТИЦАЈ ПРИМЕНЕ ИНСТРУКСІОNОG МЕТОДА НА УЧЕНИЧКО ПОСТИГНУЋЕ И МЕНТАЛНИ НАПОР: СИСТЕМИЧКИ И ТРАДИЦИОНАЛНИ ПРИСТУП У СРЕДЊЕШКОЛСКОЈ НАСТАВИ ОРГАНСКЕ ХЕМИЈЕ
}

\begin{abstract}
Многи ученици насредњешколском нивоусматрајудаје органскахемија Ancтракm тешка и апстрактна заучене и разумеване. Управозбогтога, честосе ослањајунамеханичкозапамћивање концепата из овогдомена. Наосновутога, први задатак у оквиру овог истраживањ а био је да се испита да ли системички приступ, уз примену системичких задатака синтезе, [SSynQs], као нових инструкционих алата, може да помогне ученицима у превазилажењу поменутих тешкоћа. Резултати ове студије су показали да ученици из експерименталне групе, који су били обучавани применом системичкихзадатака синтезе, [SSynQs], остварујубоља постигнућа на финалном тесту знана од ученика обучаваних традиционалном наставом, посматрајући ученичка постигнућа у конвенционалним задацима, [LQs], и системичким задацима, [SSynQs]. Ови резултати су праћени редукцијом нивоа уложеног менталног напора код ученика експерименталне групе, који су процењени у току решавања обе групе питања. У наставку, потврђено је да су ученици из обе испитиване групе мане ефикасни у току решавања системичких задатака, [SSynQs], него у току решавања конвенционалних задатака, [LQs], остварујући нижа постигнућа и бележећи више нивое менталног напора. Ти резултати су објашњени ефектом решавање задатака комплетирања, који је добро познат у оквиру теорије когнитивног оптерећења. Имајући ово у виду, следећи корак у нашем истраживану биће посвећен испитивану утицаја ефекта варијабилитета на ученичку успешност решавана системичких задатака синтезе, [SSynQs].
\end{abstract}

Кључне речи: системички приступ подучавању и учењу хемије, системички задаци синтезе, [SSynQs], конвенционални задаци, [LQs], постигнуће, ментални напор.

\section{ВЛИЯНИЕ МЕТОДА ИНСТРУКЦИИ НА УСПЕВАЕМОСТЬ И ПСИХИЧЕСКОЕ НАПРЯЖЕНИЕ УЧАЩИХСЯ: СИСТЕМНЫЙ И ТРАДИЦИОННЫЙ ПОДХОДЫ К СРЕДНЕШКОЛЬНОМУ ОБУЧЕНИЮ ОРГАНИЧЕСКОЙ ХИМИИ}

\begin{abstract}
Резюме
Многие ученики средней школы считают учебные содержания по органическойхимииотвлеченными и непонятнымии, поэтому, оничасто мехнически запоминают учебный материал. Исходя из этого, первой задачей данного исследования было установить, может ли системный подход, с использованием системныхзаданий синтеза [SSynQs] в качестве нового учебного инструмента, помочь ученикам преодолеть вышеупомянутые трудности. Результаты исследования показали, что ученики экспериментальной группы, которые обучались с помощью
\end{abstract}


The influence of instructional method on students' achievement and mental...

системных заданий синтеза [SSynQs], показали лучшие результаты на итоговом тестировании знаний, чем ученики, обучающиеся традиционным способом, в решении как конвенциональных [LQs], так и системных заданий [SSynQs]. Данные результаты сопровождались редукцией уровня умственных усилий у учеников экспериментальной группы при решении всех поставленных заданий. Кроме того, в исследовании подтверждено, что ученики обеих групп - менее эффрективны в решении системных заданий [SSynQs], чем в решении стандартных заданий шЛQся, при более высоком уровне умственных усилий. Это обяясняется эффректом задач завершения, хорошо известным в теории когнитивной нагрузки. Имея это в виду, следующим шагом в нашем исследовании должно быть рассматрение влияния эффекта изменчивости на успех учашихся в решении системныхзаданий синтеза [SSynQs].

Ключевые слова: системный подход к преподаванию и обучению химии, системные задания синтеза [SSynQs], стандартные задания [LQs], успеваемость, умственные усилия.

\section{Introduction}

Many studies dedicated to teaching and learning chemistry have emphasized that students at the secondary level consider chemistry as an abstract and difficult subject for learning and understanding (Nieswandt, 2001; Sirhan, 2007). Conducting the research in Serbia, Brković et al. (1998) found that secondary school students are the least motivated to learn chemistry, considering 14 different subjects. Low motivation was followed by students' self-evaluation of the lowest efficiency in chemistry class.

Chemical discipline, which has attracted the attention of many educators and researchers, is organic chemistry. Students often have negative attitude towards organic chemistry, as they do not possess skills and abilities which are needed for learning and understanding organic chemistry concepts - ability to think about abstract concepts, three-dimensional and analytical thinking (Carpenter \& McMillan, 2003; Mahajan \& Singh, 2005). Paulson (1999) has stated that such problem could be effectively solved by applying new instructional methods. Although there is interest for implementation of new methods in organic chemistry teaching and learning process, many chemistry teachers are still relying on traditional approach and frontal teaching (Zoller \& Pushkin, 2007). Overwhelming amount of material in textbooks and teachers' concern that they would not cover all the curricula contents, could be considered as the most common reason for that. In addition, some teachers are afraid of losing control of the classroom, if they apply some new instructional method (Paulson, 1999).

Nevertheless, literature presents articles describing instructional methods which have been evaluated as more effective than traditional organic chemistry classes. After active and cooperative learning strategy (Paulson, 1999) and peer-led team learning approach (Tien et al., 2002), Fahmy and Lagowski (2003) have introduced and evaluated systemic approach as a new instructional method which could improve students' meaningful learning and understanding. 


\section{Theoretical background}

\section{Systemic approach to teaching and learning chemistry}

Relying on Ausubels' (2000) constructivist theory of learning and meaningful learning, Fahmy and Lagowski (2003) have designed, implemented and evaluated a systemic approach to teaching and learning chemistry. The central construct of the systemic approach is the concept of "system" which generally refers to a complex whole of the interconnected parts or components (Vachliotis et al., 2014). Mentioned characteristics of the system were observed in developing new instructional tools within a systemic approach - so called systemic diagrams or systemics.

Fahmy and Lagowski (2003) have presented systemic diagrams defining them as an arrangement of concepts through interacting system in which all relations between concepts are clearly stated. Through the process of constructing systemic diagrams, these two authors have followed the main features of concept maps. Systemic diagrams and concept maps, as ontological models of knowledge representation, have the same structure elements: concepts closed in boxes or circles and lines which show how the concepts are interconnected. Additionally, these ontological models enhance meaningful learning and understanding. Ausubel (2000) described meaningful learning as process of acquiring new information which is related with appropriate aspect of student's cognitive structure. Student actively participates in that process, trying to form a bound between new concepts and those previously acquired. Furthermore, the main difference between systemic diagrams and concept maps should be mentioned. While concept maps have static, hierarchical arrangement of concepts, systemic diagrams present more or less dynamic, closed systems (Fahmy \& Lagowski, 2003). According to this, the application of systemic diagrams in educational process requires transformation of teaching material from linear arrangement (Figure 1.a) to the arrangement of closed cluster (Figure 1.b) (Fahmy, 2014).

Figure 1. Linear (a) and systemic (b) arrangements of concepts

a)

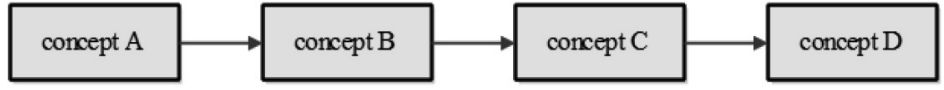

b)

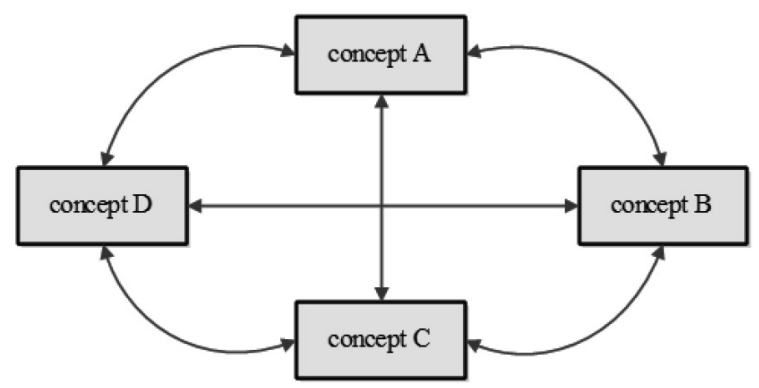


The influence of instructional method on students' achievement and mental...

In the literature, systemic diagrams have been introduced as instructional tools used for visual representation of all relevant concepts within specific teaching unit. Efficiency of systemic diagrams as instructional tools has been compared to traditional teaching method, considering one variable: the students' achievement. The results of empirical studies which were conducted on primary (Al-bashaireh, 2011; Hrin et al., 2014), secondary (Fahmy \& Lagowski, 2002, 2003) and tertiary educational levels (Fahmy \& Lagowski, 2002; Golemi et al., 2014), emphasized the fact that students who were taught by applying systemic diagrams in chemistry classes achieved higher scores on final testing than students taught by traditional method.

Few years later after systemic diagrams have been presented and evaluated Fahmy and Lagowski (2004) introduced systemic questions at the European conference on research in chemical education in Istanbul. Systemic questions were presented as new assessment schemas within systemic approach. The main differences between systemic questions and systemic diagrams, as their precursors, are in the number of concepts included in their structures, as well as in their application (Hrin et al., 2015a). As indicated previously, systemic diagrams have been constructed as instructional tools, and as such, they possess relatively large number of concepts. On the other hand, systemic questions include less number of concepts, as they are originally designed for evaluation of students' meaningful understanding (Fahmy \& Lagowski, 2012), after thez become familiar with specific teaching material.

The empirical findings emphasized that systemic questions could be characterized as effective, valid and reliable tools for assessing students' meaningful understanding (Hrin et al., 2015a; Vachliotis et al., 2011, 2014) and systems thinking (Vachliotis et al., 2014) in organic chemistry domain. The latest study within systemic approach has considered the application of systemic questions as instructional tools, including one additional variable - students' cognitive load (Hrin et al., 2015b). The main results of this study indicated that systemic synthesis questions [SSynQs] - a specific form of systemic questions, besides on students' achievement, could also have positive impact on students' cognitive load.

\section{Cognitive load theory}

The cognitive load theory (CLT) is a psychological theory which considers psychological construct formed in human brain, resulting from a specific instruction (Moreno \& Park, 2010). Within CLT the two main constructs are cognitive load (the theory was named after this term) and learning. Thereby, CTL was developed with the aim to explain the effect of instructional design on these two constructs (Moreno \& Park, 2010).

Cognitive load is a multidimensional construct, which presents the load that learning a new content or solving a particular task imposes on the individual cognitive system (cited in Paas et al., 2003). As such, cognitive load has a measurable dimension which includes three measurable concepts: mental load, mental effort, and the student's achievement which could be measured by the number of correct answers, 
number of errors or by the time spent on a task. Additionally, mental load is imposed by task requirements, while mental effort represents the amount of controlled cognitive processing depending on the student's characteristics (cognitive capabilities, cognitive style, and prior knowledge), instructional method characteristics, and task characteristics (task structure, task novelty, element interactivity) (cited in Paas et al., 2003). According to this, measuring of mental effort reveals many important information about cognitive load.

Within CLT researchers have provided several methods or procedures for mental effort measurement, which could be classified as objective and subjective methods. The objective methods are based on direct physiological measures and include the technique of functional magnetic resonance imaging (fMRI - measuring of brain activity), method of galvanic skin response (GSR) (Brünken et al., 2010), eye-tracking technique, and cardiovascular indicators (Whalen, 2007). However, mentioned techniques often require sophisticated equipment, and as such, they are not convenient for classical teaching and learning environments (Brünken et al., 2010). Considering that these facts, many researchers have chosen to apply subjective techniques, which are based on the assumption that individuals can estimate their own cognitive processes and rate the amount of perceived mental effort in a specific situation (Brünken et al., 2010). The most commonly used subjective techniques for assessing invested mental effort are seven and nine point self-rating Likert scales (Brünken et al., 2010; Kalyuga, 2009). As the most obvious benefit of such scales, Brünken et al. (2010) emphasized their simplicity, while Kalyuga (2009) stated their nonintrusive nature and cost and time effectiveness.

\section{Research Methodology}

\section{Research goal}

According to the literature review, the aim of this study was set up to examine the impact of [SSynQs] as new instructional tools on secondary school students' achievement and mental effort. In order to investigate if application of [SSynQs], could advance acquisition of organic chemistry knowledge with an investment of optimal levels of mental effort, in relation to traditional method, the following two main research questions were defined:

1. Are there statistically significant differences in students' achievement in conventional, linear questions [LQs] and [SSynQs] between experimental and control groups?

2. Are there statistically significant differences in students' mental effort in conventional, linear questions [LQs] and [SSynQs] between experimental and control groups?

Additionally, it was of particular interest to examine whether students from the same group perceive [LQs] and [SSynQs] differently. The main significance of this study could be reached from this research point. 
The influence of instructional method on students' achievement and mental...

\section{Research sample}

The present study took place in one urban high school located in Novi Sad, Serbia. Four third-grade classes of 119 students, who were 17-18 years old, participated in the study. For the purpose of study intervention, students were divided into two groups - one experimental (treated by applying [SSynQs]) and one control group (treated by applying traditional approach). On the basis of final average chemistry grade achieved at the end of previous school years (first and second grades), the groups were equalized before the research was conducted. Since the data were not normally distributed (Shapiro-Wilk test; experimental group: $W=0.830, p=0.000, p<0.05$; control group: $W=0.792, p=0.000, p<0.05)$, the Mann-Whitney test was applied for comparing the medians of the experimental and control groups. The obtained results confirmed that there was no significant difference between the experimental and control groups, since for $U=1675.00$, $p$-value was greater than $0.05(p=0.653)$. Thus, the experimental group consisted of 65 students and the control group consisted of 54 students.

\section{Research design}

The intervention was conducted during second semester of the 2012/2013 school year, and it contained two main phases. During the first phase, the students from both experimental and control groups were processing new teaching material ("Alcohols, phenols and ethers") by applying traditional approach on classes. During that phase, all students were treated equally.

The Second phase was dedicated to the revision of selected teaching units, which were presented by the teacher during the first phase. Namely, the students revised the following: preparation principles of alcohols, chemical properties of alcohols, chemical properties of phenols, preparation principles of ethers and chemical properties of ethers. However, while the control group continued with traditional classes during second phase (they were solving conventional, linear questions), the experimental group was subjected to experimental teaching by applying [SSynQs]. Authors of this paper prepared learning sheets which contained set of unfilled and partially filled [SSynQs]. Example of one [SSynQs] with four fields is provided in the Figure 2. The task was defined as follows: "In the fields B and C write the structures and names of the compounds which can be obtained by dehydration of the compound A, 3-methyl-2-butanol. Additionally, in the field $D$, write the structure and the the name of the compound which can be obtained by the Lucas test on 3-methyl-2-butanol in the presence of zinc(II)-chloride and concentrated hydrochloric acid." While the students were completing learning sheets, the teacher used Power Point presentation so that all students could see the correct answer at the end. 
Figure 2. Example of [SSynQs] which was applied in the experimental class

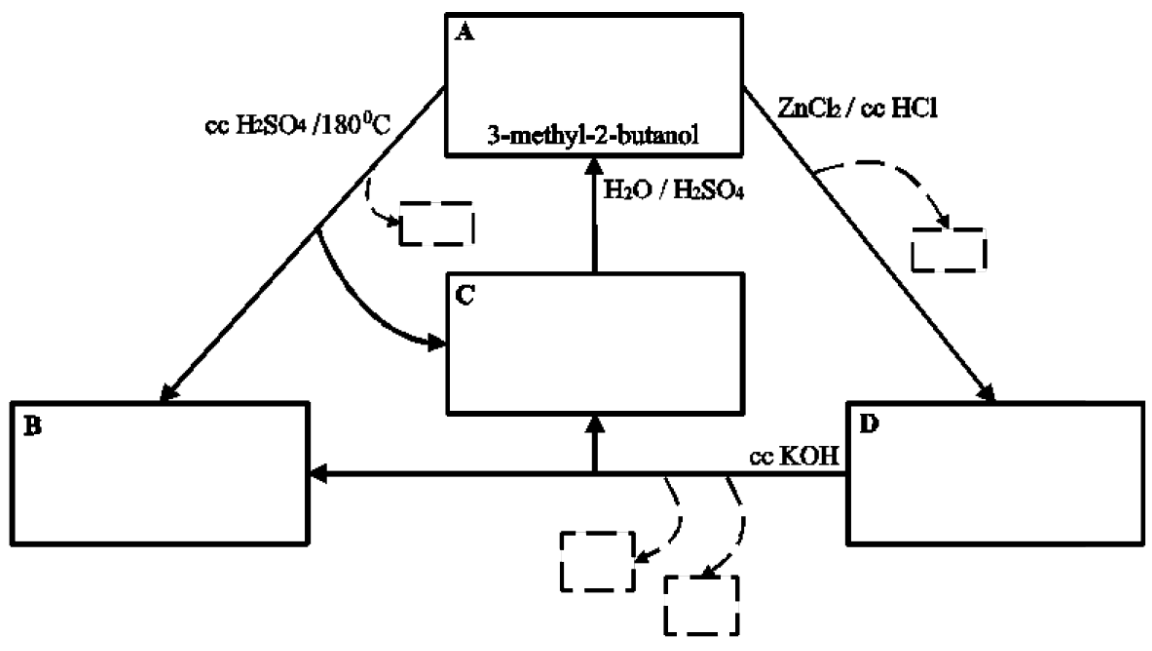

Research instruments

The research instruments in this study included a test of knowledge for measuring achievement and Likert scale for measuring invested mental effort.

a) Test of knowledge. After the second phase of the intervention, 91 students (51 from the experimental group and 40 from control group) were solving the knowledge test, during one school class in April 2013. The test contained 10 tasks which were divided into two main categories: [LQs] and [SSynQs] (Q4, Q8, Q10). [LQs] were presented as comparison question (Q1), multiple choice questions (Q2, Q3, Q7), completion question (Q5), linking question (Q6), and essay type question (Q9). Each requirement of the task was scored with one point, so the maximum possible achievement score on test was 22 points ( 11 points for [LQs] and 11 points for [SSynQs]). In order to estimate the reliability of the applied test, a Cronbach's alpha was considered. The Cronbach's alpha coefficient obtained was $a=0.72$, and according to Frisbie (1988) indicates a good reliability of this test.

b) Likert scale. In order to evaluate the students' mental effort during solving test questions, the seven-point Likert scale with descriptors: extremely easy (1), very easy (2), easy (3), neither easy nor difficult (4), difficult (5), very difficult (6) and extremely difficult (7), was presented after each task. This instrument was prepared in accordance with Kalyuga et al. (2000) and evaluated by calculation of Cronbach's alpha coefficient $(a=0.81)$, which indicated a very good reliability of this instrument.

The obtained results were analyzed by using IBM SPSS Statistics 19 software program. 
The influence of instructional method on students' achievement and mental...

\section{Results and Discussion}

\section{Analysis of the students' achievement}

The first task of this study was to examine the effectiveness of the systemic approach by applying [SSynQs] in the educational process in terms of improving the secondary school students' achievement in organic chemistry domain. In order to determine whether there was a statistically significant difference in students' achievement in [LQs] and [SSynQs] between the experimental and control groups, the $t$-test was applied. The $t$-test results (Table 1) showed that there was a significant difference in the students' achievement between the two groups, in a favor of the experimental group in both [LQs] $\left(t=5.21\right.$ for $\mathrm{df}=89$ and $\left.t_{c}=1.99 ; \mathrm{p}=0.000, \mathrm{p}<0.05\right)$ and [SSynQs] $(t=4.36$ for $\mathrm{df}=89$ and $\left.t_{c}=1.99 ; \mathrm{p}=0.000, \mathrm{p}<0.05\right)$.

Table 1. Results of the t-test for analyzing differences between the experimental and control group students' achievements in [LQs] and [SSynQs]

\begin{tabular}{|l|c|c|c|c|c|c|c|c|}
\hline \multirow{2}{*}{ Group } & \multicolumn{2}{|c|}{$\mathrm{M}(\%)$} & \multicolumn{2}{c|}{ SD } & \multicolumn{2}{|c|}{$t$} & \multicolumn{2}{c|}{$\mathrm{p}$} \\
\cline { 2 - 9 } & {$[\mathrm{LQs}]$} & {$[\mathrm{SSynQs}]$} & {$[\mathrm{LQs}]$} & {$[\mathrm{SSynQs}]$} & {$[\mathrm{LQs}]$} & {$[$ [SSynQs] } & {$[\mathrm{LQs}]$} & {$[$ [SSynQs] } \\
\hline E & 79.82 & 59.82 & 1.77 & 2.25 & 5.21 & 4.36 & $0.000^{*}$ & $0.000^{*}$ \\
\hline C & 59.91 & 38.73 & 2.25 & 2.81 & & & & \\
\hline
\end{tabular}

* $\mathrm{p}<0.05 ; \mathrm{M}$ - mean score; SD - standard deviation

The following results (Table 1) confirmed that the students who were learning with [SSynQs] showed significantly better learning achievement that those who were taught by traditional method, when we examined students'achievement in conventional, linear questions, [LQs], and systemically oriented questions, [SSynQs]. These findings were in accordance with studies in which systemic diagrams (Fahmy \& Lagowski, 2002, 2003; Golemi et al., 2014; Hrin et al., 2014) and [SSynQs] (Hrin et al., 2015a, 2015b) were evaluated in chemistry educational process as effective instructional tools.

Additionally, it was important to analyze if students from the experimental and control groups had approximately the same achievement in conventional, linear questions, [LQs], and systemically oriented questions, [SSynQs]. At the beginning, it should be noted that the students from experimental group achieved mean scores which were higher than $50 \%$ in both types of questions. According to Fahmy and Lagowski (2003) this is the first indicator of students' success in final testing. On the other hand, the students from control group achieved such success only in [LQs]. However, the results of $t$-test (Table 2) confirmed a significant difference in the students' achievement in [LQs] and [SSynQs] in both the experimental group ( $t=5.49$ for $\mathrm{df}=100$ and $t_{c}=1.98 ; \mathrm{p}=0.000$, $\mathrm{p}<0.05$ ) and the control group ( $t=4.08$ for $\mathrm{df}=78$ and $\left.t_{c}=1.99 ; \mathrm{p}=0.000, \mathrm{p}<0.05\right)$. Observing the mean values for the students' achievement in [LQs] and [SSynQs] (Table 2), it was noted that students from both groups achieved better scores on conventional, linear 
questions, [LQs], than on systemically oriented questions, [SSynQs]. In order to explain these results, we have connected our findings with Francisco et al. (2002) findings on students' achievement in concept maps chemistry problems. These authors (Francisco et al., 2002) stated that students need to organize their knowledge structure in appropriate way in order to successfully solve such problems. Respectively, [SSynQs] could be successfully solved only if students have fully constructed meaningful understanding of concept. Systemically oriented questions have been previously characterized as valid and reliable tools for assessing students' meaningful understanding (Hrin et al., 2015a; Vachliotis et al., 2011, 2014), so it is understandable that students find it more difficult to solve [SSynQs] than [LQs] which could be often solved by applying rote learning (Hrin et al., 2015a; Vachliotis et al., 2011, 2014).

Table 2. Results of the t-test for analyzing differences in achievement in [LQs] and [SSynQs] in experimental and control groups

\begin{tabular}{|c|c|c|c|c|c|c|c|c|}
\hline \multirow[t]{2}{*}{ Group } & \multicolumn{2}{|c|}{ M (\%) } & \multicolumn{2}{|c|}{ SD } & \multicolumn{2}{|r|}{$t$} & \multicolumn{2}{|r|}{$p$} \\
\hline & [LQs] & [SSynQs] & [LQs] & [SSynQs] & [LQs] & [SSynQs] & [LQs] & [SSynQs] \\
\hline$E$ & 79.82 & 59.82 & 16.11 & 20.47 & \multicolumn{2}{|r|}{5.49} & \multicolumn{2}{|c|}{$0.000^{*}$} \\
\hline C & 59.91 & 38.73 & 20.48 & 25.57 & \multicolumn{2}{|c|}{4.08} & \multicolumn{2}{|c|}{$0.000^{*}$} \\
\hline
\end{tabular}

${ }^{*} \mathrm{p}<0.05$

\section{Analysis of students' mental effort}

The second research question focused on differences in levels of invested mental effort between the experimental and control groups, which were reported during solving [LQs] and [SSynQs]. The parameters from Table 3 have showed that the experimental group students reported mean mental effort scores 4.06 and the control group students 4.51, while solving [LQs]. Additionally, during solving [SSynQs] the experimental group students reported mean mental effort scores 4.59 and control group 5.91.

In order to estimate if such differences are statistically significant, the collected data were subjected to the $t$-test. The $t$-test results (Table 3 ) showed a significant difference in mental effort ratings of the two groups, in both [LQs] ( $t=-2.83$ for $\mathrm{df}=89$ and $\left.t_{c}=-1.99 ; \mathrm{p}=0.006, \mathrm{p}<0.05\right)$ and [SSynQs] $\left(t=-6.57\right.$ for $\mathrm{df}=89$ and $t_{c}=-1.99 ; \mathrm{p}=0.006$, $\mathrm{p}<0.05)$, in favor of the experimental group students, who reported lower levels of mental effort than the control group students. Paas and van Merriënboer (1994) also noted the fact that the traditional instructional method, in which conventional problems are emphasized, imposes high mental effort on students, as they use a weak problem solving method (means-ends analysis) during solving conventional problems (Kirschner, 2002). On the other hand, systemic instructional approach was able to reduce students' mental effort, as a result of learning with [SSynQs]. Such findings had been previously reported in the paper by Hrin et al. (2015b), processing another organic chemistry topic: "Hydrocarbons and halogen derivatives of hydrocarbons". 
The influence of instructional method on students' achievement and mental...

Table 3. Results of the t-test for analyzing differences in E and C group students' mental effort in [LQs] and [SSynQs]

\begin{tabular}{|c|c|c|c|c|c|c|c|c|}
\hline \multirow[t]{2}{*}{ Group } & \multicolumn{2}{|c|}{ M } & \multicolumn{2}{|c|}{ SD } & \multicolumn{2}{|c|}{$t$} & \multicolumn{2}{|c|}{$p$} \\
\hline & [LQs] & [SSynQs] & [LQs] & [SSynQs] & [LQs] & [SSynQs] & [LQs] & [SSynQs] \\
\hline$E$ & 4.06 & 4.59 & 0.70 & 0.91 & -2.83 & -6.57 & $0.006^{*}$ & $0.000^{*}$ \\
\hline C & 4.51 & 5.91 & 0.82 & 1.01 & & & & \\
\hline
\end{tabular}

${ }^{*} p<0.05$

After it had been found that the experimental group reported lower levels of mental effort than the control group during solving the final test questions, it was important to verify if there was significant difference in the students' mental effort between examined types of test questions. Results of $t$-test (Table 4) confirmed a significant difference in students' mental effort in [LQs] and [SSynQs] observing both experimental ( $t=-3.31$ for $\mathrm{df}=100$ and $\left.t_{c}=1.98 ; \mathrm{p}=0.001, \mathrm{p}<0.05\right)$ and control group $\left(t=-6.84\right.$ for $\mathrm{df}=78$ and $t_{c}=1.99$; $p=0.000, p<0.05)$. The experimental group students considered that the process of solving [LQs] was "neither easy nor difficult" (the value 4 on the seven-point Likert scale), on the other hand process of solving [SSynQs] was characterized as "difficult" (the value 5 on the seven-point Likert scale). Additionally, the process of solving [LQs] was characterized as "difficult" by control group students, who reported mean mental effort score around 6 (the value for "very difficult" on the seven-point Likert scale) during solving [SSynQs]. It could be observed that the process of solving systemically oriented questions has imposed higher levels of mental effort on both groups of students, than the process of solving conventional, linear questions. However, Kirschner (2002) noted that completion problems increase a specific type of cognitive load - a germane cognitive load, which is important for cognitive schema construction (integration of elements of information). According to this, it could be said that solving [SSynQs] encourages students to engage in cognitive processing that is directly relevant to a schema construction.

Table 4. Results of the t-test for analyzing differences in students' mental effort in [LQs] and [SSynQs] in experimental and control groups

\begin{tabular}{|c|c|c|c|c|c|c|c|c|}
\hline \multirow[t]{2}{*}{ Group } & \multicolumn{2}{|c|}{$M$} & \multicolumn{2}{|c|}{ SD } & \multicolumn{2}{|r|}{$t$} & \multicolumn{2}{|r|}{$p$} \\
\hline & [LQs] & [SSynQs] & [LQs] & [SSynQs] & [LQs & [SSynQs] & [LQs] & [SSynQs] \\
\hline$E$ & 4.06 & 4.59 & 0.70 & 0.91 & & 3.31 & & $001^{*}$ \\
\hline C & 4.51 & 5.91 & 0.82 & 1.00 & & 5.84 & & $000^{*}$ \\
\hline
\end{tabular}

${ }^{*} p<0.05$

\section{Conclusions and Implications}

The main goal of this paper was to analyze the impact of two different instructional methods on secondary school students' achievement and mental effort (self-reported cognitive load) in organic chemistry domain ("Alcohols, phenols and ethers"). Henceforth, we have included new instructional tools, [SSynQs] (experimental group), and compared their efficiency with traditional instructional method (control group) in which conventional, linear questions, [LQs], were applied. 
By observing the students' achievement, the results of this study have indicated that the students from experimental group managed to achieve better scores in solving both types of test questions, [LQs] and [SSynQs], than the students from the control group. Similar results were obtained in the section of analyzing students' mental effort, where the students from the experimental group reported lower levels of mental effort than the students from the control group, while solving both types of questions. Based on this, it could be concluded that systemic approach was effective in helping the experimental group students to link new learning experience (selected organic chemistry topic: "Alcohols, phenols and ethers") with their previous knowledge (alkanes, cycloalkanes, alkenes, dienes, alkynes, aromatic hydrocarbons, and alkyl and aryl halides) in an organized manner - a complex cognitive schema structure. Or, it could be said that [SSynQs] have positively affected the balance between the experimental group students' mental effort and achievement. These findings seem to confirm the instructional effect of [SSynQs] previously addressed by Hrin et al. (2015a, 2015b).

However, in the literature there are no papers which indicate that students from the same group could solve [SSynQs] with similar efficiency as conventional [LQs]. In this study, it was found that secondary school students seem to be more effective in solving conventional problems than systemically oriented problems. These results were further confirmed by the levels of invested mental effort. Again, students reported lower levels of invested mental effort during solving [LQs] than during solving [SSynQs]. Nevertheless, effective solving of [SSynQs], unlike [LQs], requires additional complex cognitive competencies (ability to quickly switch to appropriate topic, ability to move from known to unknown and to make connections between them) and creating sophisticated cognitive schema. Such requirements, while decreasing external cognitive load, also increase a germane cognitive load through the completion problems effect, which is well known within the cognitive load theory (CLT) (see Paas et al., 2003).

Taking into consideration the conclusions reached from this study, the main direction of our future research will be to examine how inclusion of additional variability effect within CLT influences students' ability to solve [SSynQs]. Apart from that, further consideration of students' mental effort during learning with [SSynQs], would be very important in our attention to relate systemic approach and CLT more closely.

\section{References}

Al-bashaireh, Z. (2011). Systemic Approach Effect on Achievement of Tafila School Students in Science. International Journal of Humanities and Social Science, Vol. 1, No. 3, 47-52.

Ausubel, D. P. (2000). The Acquisition and Retention of Knowledge: A Cognitive View. Dordrecht: Springer.

Brković, A., Petrović Bjekić, D. \& Zlatić, L. (1998). Motivacija učenika za nastavne predmete. Psihologija, Vol. 31, No. 1-2, 115-136.

Brünken, R., Seufert, T. \& Paas, F. (2010). Measuring Cognitive Load. In J. L. Plass, R. Moreno \& R. Brünken (Eds.), Cognitive Load Theory (pp. 181-202). Cambridge: Cambridge University Press. 
The influence of instructional method on students' achievement and mental...

Carpenter, S. R. \& McMillan, T. (2003). Incorporation of a Cooperative Learning Technique in Organic Chemistry. Journal of Chemical Education, Vol. 80, No. 3, 330-332.

Fahmy, A. F. M. \& Lagowski, J. J. (2002). Systemic Approach to Teaching and Learning Organic Chemistry: SATLC in Egypt. Chemical Education International, Vol. 3, No. 1, AN 1. Retrieved April 10, 2015 from the World Wide Web http://www.iupac.org/publications/cei/vol3/0301x0an1.html

Fahmy, A. F. M. \& Lagowski, J. J. (2003). Systemic Reform in Chemical Education: An International Perspective. Journal of Chemical Education, Vol. 80, No. 9, 1078-1083.

Fahmy, A. F. M. \& Lagowski, J. J. (2004). Using SATL Techniques to Assess Student's Achievement in Chemistry, $18^{\text {th }}$ International Conference on Chemical Education, August 3-8, 2004, Istanbul. Retrieved April 10, 2015 from the World Wide Web http://www.satlcentral.com/PowerPoint-Presentation.htm

Fahmy, A. F. M. \& Lagowski, J. J. (2012). Systemic Assessment as a New Tool for Assessing Students Learning in Chemistry Using SATL Methods: Systemic True False [STFQs] and Systemic Sequencing [SSQs] Questions Types. African Journal of Chemical Education, Vol. 2, No. 2, 66-78.

Fahmy, A. F. M. (2014). Systemic Chemical Education Reform [SCER] in the Global Era. African Journal of Chemical Education, Vol. 4, No. 1, 19-42.

Francisco, J. S., Nakhleh, M. B., Nurrenbern, S. C. \& Miller, M. L. (2002). Assessing Student Understanding of General Chemistry with Concept Mapping. Journal of Chemical Education, Vol. 79, No. 2, 248-257.

Frisbie, D. A. (1988). NCME Instructional Model on Reliability of Scores from Teacher-made Tests. Educational Measurement: Issues and Practice, Vol. 7, No. 1, 25-35.

Golemi, S., Medja, N. \& Lacej, D. (2014). Systemic Objective Tests in Medical Biochemistry Part I Metabolism of Carbohydrates. African Journal of Chemical Education, Vol. 4, No. 1, 43-55.

Hrin, T., Milenković, D., Kekez Babić, S. \& Segedinac, M. (2014). Application of Systemic Approach in Initial Teaching of Chemistry: Learning the Mole Concept. Croatian Journal of Education, Vol. 16, No. 3, 175-209.

Hrin, T., Milenković, D. \& Segedinac, M. (2015a). The Effect of Systemic Synthesis Questions [SSynQs] on Students' Performance and Meaningful Learning in Secondary Organic Chemistry Teaching. International Journal of Science and Mathematics Education, doi: 10.1007/s10763015-9620-y (prihvaćeno za štampu).

Hrin, T., Fahmy, A. F. M., Segedinac, M. \& Milenković, D. (2015b). Systemic Synthesis Questions [SSynQs] as Tools to Help Students to Build their Cognitive Structures in a Systemic Manner. Research in Science Education, doi: 10.1007/s11165-015-9470-1 (prihvaćeno za štampu).

Kalyuga, S., Chandler, P. \& Sweller, J. (2000). Incorporating Learner Experience into the Design of Multimedia Instruction. Journal of Educational Psychology, Vol. 92, No. 1, 126-136.

Kalyuga, S. (2009). Managing Cognitive Load in Adaptive Multimedia Learning. New York: Information Science Reference.

Kirschner, P. A. (2002). Cognitive Load Theory: Implications of Cognitive Load Theory on Design of Learning. Learning and Instruction, Vol. 12, No. 1, 1-10.

Mahajan, D. S. \& Singh, G. S. (2005). University Students' Performance in Organic Chemistry at Undergraduate Levels Perception of Instructors from Universities in the SADC Region. Chemistry, Vol. 14, No. 1, 25-36. 
Moreno, R. \& Park, B. (2010). Cognitive Load Theory: Historical Development and Relation to Other Theories. In J. L. Plass, R. Moreno \& R. Brünken (Eds.), Cognitive Load Theory (pp. 1-28). Cambridge: Cambridge University Press.

Nieswandt, M. (2001). Problems and Possibilities for Learning in an Introductory Chemistry Course from a Conceptual Change Perspective. Science Education, Vol. 85, No. 2, 158-179.

Paas, F., Tuovinen, J. E., Tabbers, H. \& Van Gerven, P. W. M. (2003). Cognitive Load Measurement as a Means to Advance Cognitive Load Theory. Educational Psychologist, Vol. 38, No. 1, 63-71.

Paas, F. G. W. C. \& Van Merriënboer, J. J. G. (1994). Variability of Worked Examples and Transfer of Geometrical Problem-Solving Skills: A Cognitive Load Approach. Journal of Educational Psychology, Vol. 86, No. 1, 122-133.

Paulson, D. R. (1999). Active Learning and Cooperative Learning in the Organic Chemistry Lecture Class. Journal of Chemical Education, Vol. 76, No. 8, 1136-1140.

Sirhan, G. (2007). Learning Difficulties in Chemistry: An Overview. Journal of Turkish Science Education, Vol. 4., No. 2, 2-20.

Tien, L. T., Roth, V. \& Kampmeier, J. A. (2002). Implementation of a Peer-lead Team Learning Instructional Approach in an Undergraduate Organic Chemistry Course. Journal of Research in Science Teaching, Vol. 39, No. 7, 606-632.

Vachliotis, T., Salta, K., Vasiliou, P. \& Tzougraki, C. (2011). Exploring Novel Tools for Assessing High School Students' Meaningful Understanding of Organic Reactions. Journal of Chemical Education, Vol. 88, No. 3, 337-345.

Vachliotis, T., Salta, K. \& Tzougraki, C. (2014). Meaningful Understanding and Systems Thinking in Organic Chemistry: Validating Measurement and Exploring Relationships. Research in Science Education, Vol. 44, No. 239-266.

Whelan, R. R. (2007). Neuroimaging of Cognitive Load in Instructional Multimedia. Educational Research Review, Vol. 2, No. 1, 1-12.

Zoller, U. \& Pushkin, D. (2007). Matching Higher-order Cognitive Skills (HOCS) Promotion Goals with Problem-Based Laboratory Practice in Freshman Organic Chemistry Course. Chemistry Education Research and Practice, Vol. 8, No. 2, 153-171.

\section{Подаци о ауторима}

Др Тамара Хрин је асистент на Природно-математичком факултету Универзитета у Новом Саду. E-mail: tamara.hrin@dh.uns.ac.rs

Др Мирјана Сегединац је редовни професор на Природно-математичком факултету Универзитета у Новом Саду.

E-mail: mirjana.segedinac@dh.uns.ac.rs

Др Душица Миленковић је асистент на Природно-математичком факултету Универзитета у Новом Саду. E-mail: dusica.milenkovic@dh.uns.ac.rs

Саша Хорват, мастер хемичар, је стручни сарадник за организовање наставе на Природно-математичком факултету Универзитета у Новом Саду.

E-mail: sasa.horvat@dh.uns.ac.rs 